\title{
Ramsay Hunt syndrome type II
}

Figure Ramsay Hunt syndrome type II

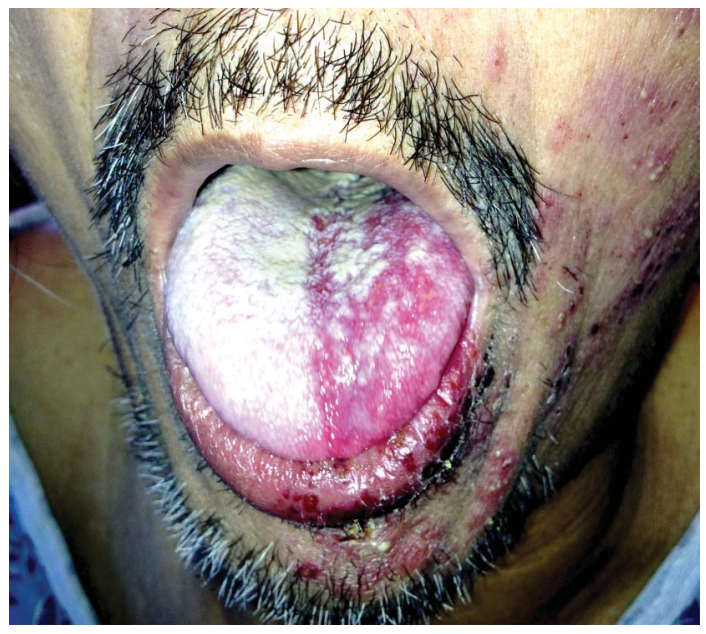

Vesicular rash involving the left anterior two-thirds of the tongue due to geniculate ganglion involvement by varicella-zoster virus reactivation eponymously named Ramsay Hunt syndrome type II. Additional lesions on the left lower lip and face are consistent with involvement of the third branch of the trigeminal nerve.

A 57-year-old man developed 3 days of left facial pain and swelling with left-sided hearing loss followed by a painful, unilateral, erythematous, and vesicular rash on the left anterior two-thirds of the tongue, external auditory canal, lip, and face typical of varicella-zoster virus reactivation (figure). Reactivation in the geniculate ganglion or facial nerve is uncommon and typically causes tongue and auricular lesions or facial palsy and was described by Hunt in 1907. ${ }^{1}$ The patient received IV acyclovir and oral prednisone with rapid improvement in pain and resolution of lesions and improvement of hearing over 1 month.

Shuhan Zhu, MD, Yelena Pyatkevich, $M D$

From Boston University School of Medicine, Boston University Medical Center, MA.

Author contributions: Shuhan Zhu: drafting/revising the manuscript, accepts responsibility for conduct of research and final approval, acquisition of data. Yelena Pyatkevich: drafting/revising the manuscript, study concept or design, accepts responsibility for conduct of research and final approval, study supervision.

Study funding: No targeted funding reported.

Disclosure: The authors report no disclosures relevant to the manuscript. Go to Neurology.org for full disclosures.

Correspondence to Dr. Zhu: Shuhan.Zhu@bmc.org

1. Hunt JR. On herpetic inflammations of the geniculate ganglion: a new syndrome and its complications. J Nerv Ment Dis 1907; 34:73-96. 


\section{Neurology}

Ramsay Hunt syndrome type II

Shuhan Zhu and Yelena Pyatkevich

Neurology 2014;82;1664

DOI 10.1212/WNL.0000000000000388

\section{This information is current as of May 5, 2014}

\section{Updated Information \& Services}

\section{References}

Subspecialty Collections

Permissions \& Licensing

Reprints including high resolution figures, can be found at: http://n.neurology.org/content/82/18/1664.full

This article cites 1 articles, 0 of which you can access for free at: http://n.neurology.org/content/82/18/1664.full\#ref-list-1

This article, along with others on similar topics, appears in the following collection(s):

Clinical neurology examination

http://n.neurology.org/cgi/collection/clinical_neurology_examination Viral infections

http://n.neurology.org/cgi/collection/viral_infections

Information about reproducing this article in parts (figures,tables) or in its entirety can be found online at:

http://www.neurology.org/about/about_the_journal\#permissions

Information about ordering reprints can be found online:

http://n.neurology.org/subscribers/advertise

Neurology ${ }^{\circledR}$ is the official journal of the American Academy of Neurology. Published continuously since 1951, it is now a weekly with 48 issues per year. Copyright @ 2014 American Academy of Neurology. All rights reserved. Print ISSN: 0028-3878. Online ISSN: 1526-632X.

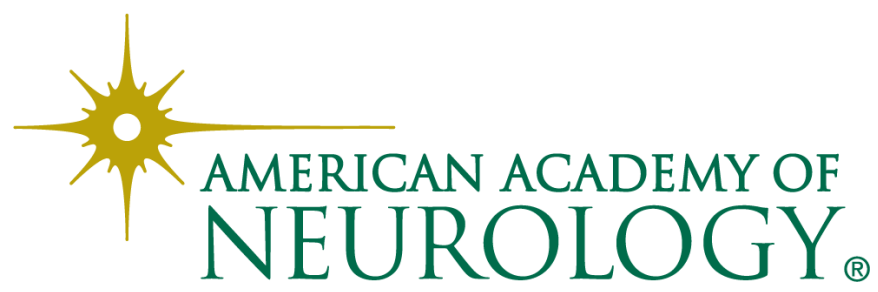

